\title{
Pandangan Masyarakat Tentang Tradisi Dhempo' dalam Proses Pertunangan (Studi Kasus di Desa Jarin Kecamatan Pademawu Kabupaten Pamekasan)
}

\author{
Fahrisal Amin \\ Institut Agama Islam Negeri (IAIN) Madura
}

\begin{abstract}
Abstrak:
Fokus masalah yang dibahas dalam kajian ini yaitu: apa alasan masyarakat Desa Jarin Kecamatan Pademawu Kabupaten Pamekasan melaksanakan tradisi dhempo? dan bagaimana pandangan masyarakat terhadap tradisi dhemo dalam proses pertunangan di Desa Jarin Kecamatan Pademawu Kabupaten Pamekasan? Setelah dilakukan penelitian, disimpulkan bahwa alasan kuat masyarakat melakukan demonstrasi salah satunya atas dasar mengikuti sesepuh sebelumnya. (The focus of the problem studied in this study, namely: what are the reasons for the community of Jarin Village, Pademawu District, Pamekasan Regency to carry out the dhempo tradition? and what is the community's view of the dhemo tradition in the engagement process in Jarin Village, Pademawu District, Pamekasan Regency? After doing the research, it was concluded that the strong reason for the community to conduct demonstrations was one of them on the basis of following the previous elders.)
\end{abstract}

Kata Kunci:

Masyarakat, Tradisi, Dhempo'

\section{Pendahuluan}

Kata perkawinan menurut istilah hukum Islam sama dengan kata 'nikah' dan kata 'zawaj'. Nikah menurut bahasa mempunyai arti yang sebenarnya (haqiqat) yakni 'dham' yang berarti menghimpit, menindih, atau berkumpul. Nikah mempunyai arti kiasan yakni berarti 
setubuh atau 'aqad' yang berarti mengadakan perjanjian pernikahan. Dalam kehidupan sehari-hari nikah dalam arti kiasan lebih banyak dipakai dalam arti sebenarnya jarang sekali dipakai saat ini. ${ }^{1}$ Tujuan perkawinan sebagaimana yang disyariatkan oleh teks suci dan undang-undang dapat diwujudkan dengan baik dan sempurna jika perkawinan tersebut sejak proses pendahulunya (muqaddimat al-zawaj) berjalan sesuai dengan ketentuan-ketentuan oleh agama. Dimana diantara proses yang akan dilalui itu adalah peminangan atau disebut dengan khitbah. ${ }^{2}$

Khitbah diartikan dengan suatu langkah pendahuluan untuk melangsungkan perkawinan. Ulama fikih mendefinisikannya dengan menyatakan keinginan pihak laki-laki kepada pihak wanita tertentu untuk mengawininya dan pihak wanita menyebarluaskan berita peminangan ini. ${ }^{3}$ Di dalam kitab-kitab fikih khitbah diterjemahkan dengan pernyataan keinginan untuk menikah terhadap seorang wanita yang telah jelas (izhar al-rughbat fi al-zawaj bi imraatin mu'ayyanat) atau memberitahukan keinginan untuk menikah kepada walinya. Adakalanya pernyataan keinginan tersebut disampaikan dengan bahasa yang jelas dan tegas (sarih) dan dapat juga dilakukan dengan sindiran (kinayah). 4

Memilih calon istri atau calon suami merupakan langkah awal untuk memulai kehidupan berumah tangga. Oleh karena itu memilih calon istri atau calon suami bukanlah hal yang mudah, membutuhkan waktu yang tidak singkat, karena harus melihat syarat-syarat calon istri atau calon suami sesuai anjuran agama. ${ }^{5}$ Orang yang hendak menikah hendaklah memilih pendamping hidup dengan cermat. ${ }^{6}$ Adapun identitas diri atau kriteria yang dapat dipertimbangkan dalam memilih pasangan adalah seperti diisyaratkan dalam hadis Nabi saw berikut ini.

${ }^{1}$ Abd. Somad, Hukum Islam Penormaan Prinsip Syariah dalam Hukum Indonesia, (Jakarta: Kencana, 2010), 273.

2Amiur Nuruddin \& Azhari Akmal Tarigan, Hukum Perdata Islam di Indonesia, (Jakarta: Kencana,2004), 82.

${ }^{3}$ Amiur \& Azhari, Hukum Perdata Islam..., 82

${ }^{4}$ Amiur \& Azhari, Hukum Perdata Islam..., 83.

5 Akhmad Farid Mawardi Sufyan, "Pandangan Masyarakat Desa Panempan Terhadap Pelaksanaan Akad Nikah Pada Bulan Muharram," Al-Manhaj 3, no. 1 (2021): 58.

'Warsita, Toty Citra. "Prosesi Peminangan Menurut Adat Bima dalam Prespektif Islam", (Skripsi, UIN Syarif Hidayatullah, Jakarta, 2010), 3. 


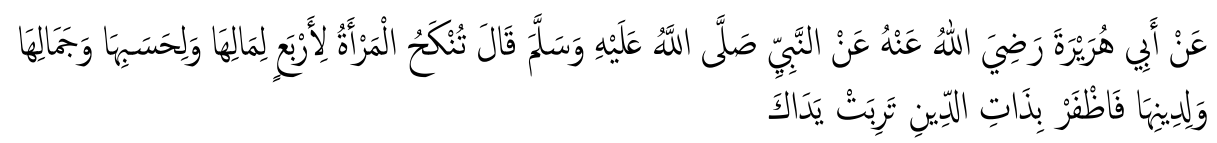

dari Abu Hurairah radliallahu 'anhu, dari Nabi shallallahu 'alaihi wasallam, beliau bersabda: "Wanita itu dinikahi karena empat hal, karena hartanya, karena keturunannya, karena kecantikannya dan karena agamanya. Maka pilihlah karena agamanya, niscaya kamu akan beruntung."(HR. Bukhari). ${ }^{7}$

Dalam pemilihan calon istri atau calon suami harus dilihat dan disesuaikan dengan perbedaan adat yang sangat jelas antara suku agar tidak terjadi penyesalan dikemudian hari. Adat berasal dari bahasa arab yang berarti kebiasaan sedangkan adat istiadat adalah pedoman hidup diseluruh daerah yang diperuntukan selama ini. ${ }^{8}$ Istilah tradisi sering digunakan dan dijumpai dalam berbagai literatur, seperti tradisi madura, tradisi jawa, tradisi keraton, tradisi petani, dan tradisi pesantren. Dalam khazanah indonesia, tradisi berarti segala sesuatu seperti adat, kebiasaan, ajaran dan sebagainya, yang turun temurun dari nenek dari nenek moyang, atau segala sesuatu yang ditranmisikan, diwariskan oleh masa lalu ke masa sekarang. ${ }^{9}$

Dalam hal ini diungkapkan mengenai cara-cara yang berlaku dalam masyarakat untuk dapat melangsungkan perkawinan. Masyarakat pada dasarnya telah menetapkan cara-cara tertentu untuk dapat melangsungkan perkawinan. Pada prinsipnya cara yang paling umum dilakukan oleh masyarakat adalah melalui peminangan. Dalam hal peminangan pada tiap masyarakat (hukum adat) yang ada di Indonesia cara yang digunakan dalam melakukan pelamaran/ peminangan pada hakikatnya terdapat kesamaan, namun perbedaanperbedaannya hanyalah (kira-kira) terdapat pada alat atau sarana pendukung proses pinangan tersebut. ${ }^{10}$

Sedangkan pada masyarakat madura, begitu hasil penelitian Herman Fajry, memiliki keunikan dalam mempertahankan adat dan

\footnotetext{
7 Siti Musawwamah, Hukum Perkawinan, (Pamekasan, STAIN Pamekasan Press, 2010), 92.

8 Toti Citra Warsita, Prosesi Peminangan Menurut Adat Bima dalam Prespektif Islam, (Skripsi, UIN Syarif Hidayatullah, Jakarta, 2010), 3.

${ }^{9}$ MF. Zenrif, Realitas Keluarga Muslim antara mitos dan doktrin agama, (Malang: UINMalang Press), 21.

${ }^{10} \mathrm{MF}$. Zenrif, Realitas Keluarga..., 4.
} 
tradisi, sekalipun adat dan tradisi terkadang berlandaskan atas mitos. Dalam masalah perkawinan, masyarakat madura mempunyai kriteria tertentu yang harus dihindari ketika menentukan calon. ${ }^{11}$ Model adat di masyarakat madura ketika ada seorang lelaki ingin mempersunting seorang gadis yang disukainya, maka langkah yang harus ia ambil pertama kali adalah menyuruh orang ketiga untuk menyampaikan maksudnya pada orangtua si gadis tersebut.

Orang ketiga yang dipilih lelaki tersebut biasanya orang yang disegani dan dipercaya, baik dari keluarganya sendiri atau bukan (misalnya seorang ustadz atau kyai). Ketika orang ketiga yang dipilih adalah orang yang berpengaruh, maka besar kemungkinan lamaran tersebut akan diterima dengan baik oleh pihak keluarga perempuan. Tentu saja sebelum menyuruh orang ketiga untuk itu, si lelaki sudah terlebih dahulu mencari informasi tentang di mana rumah si gadis, bagaimana perangainya bagaimana nasab keluarganya, dan hal penting lainnya yang patut diketahui. Setelah punya banyak informasi tentang si gadis dan dirasa cocok, pihak lelaki akan memasang kabar angin.

Dalam istilah Madura disebut "masang ngin-angin". Ini bertujuan untuk mengetahui bagaimana respon dari pihak perempuan, apakah positif ataukah justru negatif. Jika "ngin-angin" ini mendapat tanggapan yang positif dari pihak si gadis, maka si lelaki akan menyuruh orang ketiga untuk mempertegas lamaran. Nah, setelah itu pihak lelaki tinggal menunggu apakah pinangannya akan diterima atau malah sebaliknya. Jika diterima, maka seminggu setelah penyampaian maksud tersebut adalah proses lamaran yang diawali dari pihak lelaki mengunjungi rumah keluarga perempuan dengan membawa sejumlah bawaan lamaran seperti nasi ketan, sesisir pisang, aneka macam kue, kosmetik, dan pakaian untuk si perempuan.

Lalu seminggu kemudian, dari pihak perempuan lah yang akan mengunjungi rumah tunangan laki-laki. Sama dengan pihak laki-laki, dari pihak perempuan juga membawa sejumlah barang dan makanan untuk keluarga si lelaki, seperti nasi, telur, kue, dan tak lupa juga pakaian dan sarung. Orang Madura menyebut hal ini sebagai

11MF. Zenrif, Realitas Keluarga..., 24. 
"balasan". Artinya, dari pihak perempuan membalas lamaran pihak laki-laki. 12

Secara umum, itulah model tradisi adat madura dalam proses pertunangan. Namun, ada tradisi proses pertunangan lain yang dilakukan oleh masyarakat madura khususnya di daerah kabupaten pamekasan, yaitu di Desa Jarin Kecamatan Pademawu Kabupaten Pamekasan. Model tradisi yang dilakukan oleh masyarakat disana yaitu mencocokkan nama pasangan yang akan ditunangkan dengan menghitung dan menjumlahkannya menggunakan rumus-rumus tertentu.

Tradisi ini lebih dikenal oleh masyarakat Desa Jarin Kecamatan Pademawu Kabupaten Pamekasan dengan istilah dhempo'. Dalam mencocokkan nama pasangan tersebut, biasanya dari pihak laki-laki pergi ke satu tokoh untuk dimintai jawaban hasil pendhempokan itu sendiri. Apabila hasil dari pendhempokan itu baik, maka pertunangan tetap diteruskan dan akad pernikahan pun berjalan sesuai rencana. Akan tetapi jika hasil pendhempokan itu tidak baik, pertunangan tetap dilakukan, namun pada saat akad pernikahan, salah satu nama dari calon tersebut harus dirubah, dengan menambahkan nama lain. Biasanya nama yang ditambah dari pihak laki-laki dengan menambahkan nama "Ahmad" atau "Muhammad".

Pelaksanaan tradisi ini guna melihat kembali apakah pasangan pria dan wanita tersebut benar-benar sudah tepat dan cocok sehingga pernikahannya nanti sesuai dengan apa yang diinginkan sampai ajal menjemput mereka. Fenomena ini membuat peneliti tertarik untuk meneliti sejauh mana signifikasi tradisi ini sehingga kalangan masyarakat percaya dan mempunyai harapan besar terhadap pernikahan yang bahagia sakinah mawaddah wa rahmah.

Untuk menghindari meluasnya pembahasan dan agar terkait langsung pada fokus utama, maka penulis menfokuskan penelitian ini sebagai berikut: Pertama, Apa alasan masyarakat Desa Jarin Kecamatan Pademawu Kabupaten Pamekasan melakukan tradisi dhempo'? Kedua, bagaimana praktek tradisi dhempo' yang dilakukan masyarakat Desa Jarin Kecamatan Pademawu Kabupaten Pamekasan? Ketiga,

12Sakera Media, "Tradisi Pertunangan di Madura", Emadura, diakses dari http://www.emadura.com/2015/06/tradisi-pertunangan-di-madura.html, pada tanggal 26 Februari 2021pukul 20:08. 
bagaimana pandangan masyarakat tentang tradisi dhempo' dalam proses pertunangan di Desa Jarin Kecamatan Pademawu Kabupaten Pamekasan?

\section{Pengertian, Dasar hukum, Khitbah (Peminangan)}

Kata Khithbah berasal dari bahasa Arab (الخطبة) yang artinya pinangan, lamaran atau meminang. Lebih spesifik peminangan secara linguistikpeminangan berasal dari kata "pinang" dengan mendapat imbuhan pe - an. Peminangan diartikan proses, cara atau perbuatan meminang. Khithbah merupakan suatu aktifitas sebagaimana halnya duduk dan berkumpul. Anda berkata, seseorang melakukan khitbah (meminang) terhadap seorang perempuan. Artinya, dia meminang dan mengajak perempuan (yang dipinangnya) untuk menikah dengan cara yang umum dilakukan orang. ${ }^{13}$

Dasar hukum peminangan ini Islam telah mengturnya dalam konteks hubungan antara sesama manusia dalam berbagai aspek hukum perkawinan. Kehidupan manusia akan berjalan dengan baik dan sempurna apabila berpedoman pada ajaran agama Islam. Sebaiknya bila manusia meninggalkan aturan Islam maka kemenduruan dan kerusakan yang akan menimpa umat manusia dalam semua aspek.

Salah satu yang menjadi bagian yang diatur dalam ajaran agama Islam adalah mengenai peminangan. Peminangan merupakan suatu hal yang dianjurkan oleh Islam bagi seseorang yang akan melaksanakan perkawinan, karena tanpa adanya proses peminangan maka perkawinan mustahil dapat dilaksanakan. Islam telah mengajarkan tentang peminangan, dan hal tersebut merupakan suatu wujud pembolehan terhadap peminangan itu sendiri. Dalam al-Quran surat Al-Baqarah ayat 235 disebut sebagai berikut:

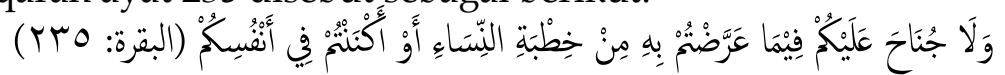

"Dan tidak ada dosa bagi kamu meminang wanita-wanita itu dengan sindiran atau kamu menyembunyikan (keinginan mengawini mereka) dalam hatimu" ${ }^{14}$

\footnotetext{
13Suhaimi, "Praktik Khitbah di Madura Perspektif Hukum Islam dan Hukum Adat", AlIhkam, Vol. 9 No.2 (Desember, 2014), 297.

14Suhaimi, "Praktik Khitbah..", 297
} 
Sebelum melangkah kedalam kehidupan rumah tangga guna terciptanya kesejahteraan dan ketentraman dalam berkeluarga sebagai suami istri hendaknya, calon suami atau istri lebih dulu melihat calonnya sehingga dapat diketahui baik buruknya atau hal yang menjadi ketertarikannya. Waktu berlangsungnya peminangan laki-laki yang melakukan peminangan diperbolehkan melihat perempuan yang dipinangnya, meskipun menurut asalnya seorang laki-laki haram melihat kepada perempuan. ${ }^{15}$ Islam membolehkan untuk melihat calon tunangan atau wanita yang hendak dilamar, namun ada beberapa yang harus diperhatikan dalam melihat karena tidak semua anggota tubuh dapat dilihat akan tetapi hanya sebatas yang diperbolehkan menurut syara' atau dengan batasan-batasan tertentu.

Kembali pada pembahasan ini bahwa dhempo' ini adalah prosesi pertunangan yang juga menjadi bagian dari adat istiadat, maka perlu dipahami bahwa kebiasaan seperti ini didefinisikan sebagai urf. Adapu urf sendiri adalah bentuk-bentuk mu'amalah (hubungan kepentingan) yang telah menjadi adat kebiasaan dan telah berlangsung (konstan) di tengah masyarakat. Hal ini tergolong salah satu sumber hukum dan dalil dari ushul figh yang diambil dari intisari sabda Nabi Muhammad SAW. Sebagai berikut:

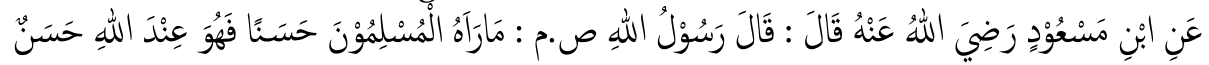
Artinya: Dari Ibn Mas'ud ra., dia berkata: Rasulullah SAW. Bersabda: apa-apa yang menurut orang-orang muslin itu baik, niscaya menurut Allah SW. juga baik. (HR. Ahmad). ${ }^{16}$

Secara sosiologis, sebuah tradisi terbentuk dan bertahan dalam masyarakat karena mereka menganggap bahwa tradisi yang dianutnya baik secara objektif maupun subjektif. Dengan kata lain, antara tradisi dan masyarakat mempunyai interkorelasi yang simbiosis mutualistik dalam memberikan makna. MF. Zenrif mengutip dari Bawani, Beberapa makna tradisi bagi masyarakat ialah sebagai wadah ekspresi keagamaan, sebagai alat pengikat kelompok dan sebagai benteng pertahanan kelompok.

\footnotetext{
${ }^{15}$ Amir Syarifuddin, Garis-Garis Besar Fiqih (Jakarta: Kencana, 2003), 85.

${ }^{16}$ Amiruddin \& N. Fathurrahman, Pengantar Ilmu Figh, (Bandung: Reflika Aditama, 2016), 67.
} 


\section{Profil Desa Jarin Kecamatan Pademawu Kabupaten Pamekasan}

Desa Jarin merupakan salah satu desa yang ada di Kecamatan Pademawu Kabupaten Pamekasan yang mayoritas masyarakatnya bekerja sebagai petani dan peternak. Desa ini mempunyai potensi pertanian dan peternakan yang beraneka ragam yaitu jagung, padi, tembakau, cabe, kacang ijo, ayam, sapi, kambing dan lain-lain. Namun dengan potensi desa yang beraneka ragam dari hasil pertanian dan peternakan para petani maupun peternak masih belum merasakan kesejahteraan dan kemakmuran, hal ini disebabkan cuaca yang berubah-ubah dan juga pemahaman masyarakat terhadap cara bertani yang baik, sehingga masyarakat sering mengalami gagal panen, hasil tani tidak maksimal dan ditambah banyaknya masyarakat kesulitan dalam pemenuhan ekonomi keluarga dengan sempitnya lapangan pekerjaan. Di samping itu, juga keadaan modal yang sedikit sehingga menghambat bagi masyarakat untuk membuka usaha lainnya.

Desa jarin secara monografis dapat dijelaskan secara singkat sebagai berikut :

$\begin{array}{ll}\text { Nama Desa } & : \text { Jarin } \\ \text { Nomor Kode } & : 07 \\ \text { Kecamatan } & : \text { Pademawu } \\ \text { Kabupaten/Kota } & : \text { Pamekasan } \\ \text { Propinsi } & : \text { Jawa Timur } \\ \text { Luas Desa } & : 494,30 \text { Ha } \\ \text { Batas Wilayah } & \\ \quad \text { Sebelah Utara } & \text { : Desa Durbuk } \\ \quad \text { Sebelah Selatan } & \text { : Desa Pegagan } \\ \quad \text { Sebelah Barat } & \text { : Desa Baddurih } \\ \quad \text { Sebelah Timur } & \text { : Desa Majungan }\end{array}$

Kondisi Geografis

Ketinggian tanah dari permukaan laut $\quad$ : 7 Meter

Banyaknya curah hujan :-

Topografi (daratan rendah, tinggi, pantai : Daratan Rendah

Orbitasi (jarak dari pusat pemerintahan)

Jarak dari Pusat Pemerintahan Kecamatan : $: 7 \mathrm{Km}$

Jarak dari Ibukota Kabupaten $\quad: 10 \mathrm{Km}$ 
Pandangan Masyarakat Tentang Tradisi Dhempo' dalam Proses Pertunangan (Studi Kasus di Desa Jarin Kecamatan Pademawu Kabupaten Pamekasan)

Jarak dari Ibukota Propinsi

: $132 \mathrm{Km}$

Jarak dari Desa Ke Ibukota Negara

: $1.132 \mathrm{Km}$

Jumlah Penduduk

Laki-laki

: 2.139 orang

Perempuan

: 2.258orang

Jumlah

Kepala Keluarga

: 4.397orang

: $1.410 \mathrm{KK}$

\section{Alasan Masyarakat Desa Jarin Kecamatan Pademawu Kabupaten Pamekasan Melakukan Tradisi Dhempo'}

Pertama, Peneliti menemukan bahwa alasan masyarakat desa Jarin menggunakan tradisi dhempo' atas dasar ikut-ikutan dari sesepuh sebelumnya. Karena tradisi ini sudah sejak lama menjadi kebiasaan orang Jarin apabila anaknya akan ditunangkan. Kedua, Karena adanya perasaan was-was dari perkataan sesepuh, dan menjadi kebutuhan masyarakat.

Maka kemudian tradisi dhempo' ini tetap dilakukan oleh masyarakat. Ketiga, Tidak lain hanyalah untuk mencari kebaikan dan kepentingan kegiatan lain yang mengarah kepada harmonisnya rumah tangga. Keempat, Sebagai usaha manusia untuk mencari jodoh. Meskipun sudah ada takdir yang menentukan. Kelima, Karena ada keterangan di dalam kitab Syamsul Maarif dan Abu Ma'syar Al-Falaki.

\section{Praktek Tradisi Dhempo' di Desa Jarin Kecamatan Pademawu Kebupaten Pamekasan}

Pertama, Praktek dalam tradisi dhempo' dilakukan pada saat calon laki-laki mau bertunangan dengan seorang perempuan, serta untuk meminta dhempo' itu tidak harus membawa apa, yang penting membawa nama calon kedua pasangan untuk dihitung oleh pelaku dhempo', sekaligus membawa uang sebagai tanda terimakasih. Kedua, Waktu meminta dhempo' itu pada saat dalam perencanaan menyunting seorang wanita. ada dua versi dan cara untuk mendhempo'. Ada versi jawa dan ada juga versi arab. Dan apabila misalnya ketika di dhempo' tidak baik, namun tetap ingin dilanjutkan. Maka ada jalan alternatifnya, yaitu mengubah, menambah atau mengurangi nama pada waktu penyebutan akad nikah. Alternatif tersebut tergantung 
kondisi dari nama calon tersebut. Apakah lebih baik diubah, ditambah atau akan dikurangi.

Ketiga, Terkait nama yang akan dihitung adalah huruf hidup dari nama panjangnya. Ketentuannya jika laki-laki, dipisah al nya, kalau ada nama muhammad atau ada nama bapaknya di belakang, maka dibuang. Caranya, setelah kedua nama dijumlahkan, maka ditambah 7 lalu dibagi 9, maka hasilnya akan diketahui. Menurut versi arab dengan menggunakan kitab Syamsul Maarif. Keempat, Ada juga terkait cara penjumlahan nama, yang dihitung itu huruf hidup dari nama depan dan belakangnya saja. Alasannya, karena di tujukan dunia dan akhiratnya dari nama tersebut. Setelah itu dijumlahkan lalu dibagi 5 , yang 5 itu hitungannya (sandang, pangan, gedung, larah, dan pateh). Ini menurut versi jawa dengan menggunakan kitab primbon bataljemur adammakna.

Kelima, Adanya rokat (selamatan) dengan menyembelih ayam berwarna hitam pekat pada waktu pernikahan. Katanya, dhempo' itu berkaitan dengan pelaku, menilai baik/tidaknya pertunangan sampai pernikahan nanti. Dan rokat berhubungan dengan rezeki keduanya (calon suami istri). Keenam, Terjadinya tradisi dhempo' diawali dengan adanya satu kejadian, dan kejadian itu ternyata terjadi secara berulangulang. Maka kemudian sama orang dulu itu ditulis dan menjadi suatu catatan pribadi, catatan tersebut lalu diturunkan kepada anak-anaknya hingga tersebar dan menjadi pegangan yang diyakini oleh masyarakat sampai sekarang. Ketujuh, Awal kepercayaan masyarakat yaitu dulu ketika orang itu tidak waswas, tidak melakukan. Tapi karena waktu itu perkataan sesepuh banyak kenyataan dari hasil dhempo' nya, maka akhirnya menjadi keyakinan masyarakat kalau mau tunangan harus di dhempo' dahulu.

\section{Pandangan masyarakat tentang tradisi dhempo' dalam proses pertunangan di Desa Jarin Kecamatan Pademawu Kebupaten Pamekasan}

Pertama, Dhempo' adalah sebutan dari gabungan nama untuk melihat baik tidaknya suatu hubungan. Lapangan dhempo' itu bukan dalam hal nikah saja, segala hal yang mempunyai hubungan itu bisa di dhempo'. Kedua, Asal usul ilmu dhempo' itu dari ulama'. ilmu ini langsung dari Allah, bukan buatan atau karangan manusia. Ilmu ini tidak melanggar syariat, justru ini bergandingan dengan syariat karena 
berlandaskan dalil dan ada kaidahnya. Ketiga, Dhempo' bagi masyarakat Desa Jarin sebagai bentuk ikhtiar atau usahanya orang awam, kalau di kalangan kyai dengan sholat istikharah. Keempat, Dhempo' itu hanya perkiraan, manusia itu hanya berusaha agar dipertemukan dengan kebaikan. Semuanya kembali ke takdir masingmasing orangnya.

\section{Penutup}

Berdasarkan pemaparan di atas, maka disimpulkan bahwa alasan masyarakat Desa Jarin Kecamatan Pademawu Kabupaten Pamekasan melakukan tradisi dhempo', antara lain: Masyarakat Desa Jarin menggunakan tradisi dhempo' atas dasar ikut-ikutan dari sesepuh sebelumnya. Karena tradisi ini sudah sejak lama menjadi kebiasaan orang Jarin apabila anaknya akan ditunangkan; Adanya perasaan waswas dari perkataan sesepuh, dan dipandang menjadi kebutuhan masyarakat. Maka kemudian tradisi dhempo' ini tetap dilakukan oleh masyarakat; Tidak lain hanyalah untuk mencari kebaikan yang mengarah pada terciptanya rumah tangga yang harmonis yang sesuai dengan ukuran/ standar yang ditentukan; Sebagai usaha manusia untuk mencari jodoh, meskipun sudah ada takdir yang menentukan; Berdasarkan keterangan di dalam kitab Syamsul Maarif dan Abu Ma'syar Al-Falaki.

Selain itu praktek dalam tradisi dhempo' dilakukan pada saat calon laki-laki ingin bertunangan dengan seorang perempuan. Artinya ketika ada kebutuhan yang berkaitan dengan pertunangan, maka pada saat itulah dhempo' ditanyakan oleh masyarakat kepada orang yang ahli dhempo'. Ada dua cara dalam mendhempo' nama seseorang, yaitu: kesatu, cara penjumlahan nama yang dihitung dari huruf hidup dari nama depan dan belakang. Alasannya, karena di tujukan dunia dan akhiratnya dari nama tersebut. Setelah itu dijumlahkan lalu dibagi 5, yang 5 itu hitungannya (sandang, pangan, gedung, larah, dan pateh). Ini menurut versi jawa dengan menggunakan kitab primbon bataljemur adammakna. Kedua, Cara penjumlahan nama yang dihitung huruf hidup dari nama panjangnya. Ketentuannya jika laki-laki, dipisah al nya, kalau ada nama muhammad atau ada nama bapaknya di belakang, maka dibuang. Caranya, ubah nama menjadi huruf hijaiyah, setelah itu kedua nama dijumlahkan, lalu ditambah 7 kemudian dibagi 
9. Untuk mencari hasil dari penjumlahan tersebut diambil dari sisanya. Menurut versi arab dengan menggunakan kitab Syamsul Maarif.

Menurut masyarakat Desa Jarin asal mula adanya tradisi ini belum diketahui secara jelas. Ada yang mengatakan dari nenek moyang, dari sesepuh, dan ada juga yang mengatakan ilmu perhitungan ini langsung dari Allah dan dilanjutkan oleh para ulama' karena ada dalam sebuah kitab. Penggunaan dhempo' menurut beberapa masyarakat berbeda-beda, namun pada intinya bertujuan untuk kebaikan anaknya. Para orang tua tidak lepas tanggung jawab untuk berusaha mencarikan yang terbaik bagi anak-anak mereka. Dan mereka sangat yakin, usaha mereka akan berakhir dengan adanya takdir Allah swt.

\section{Daftar Pustaka}

Al-Faifi, Syaikh Sulaiman Ahmad Yahya. Ringkasan Fikih Sunnah Sayyid Sabiq. Jakarta: Pustaka Al-Kautsar. 2013.

Alhamdani. Risalah Nikah Hukum Perkawinan Islam. Jakarta: Pustaka Amani, 1989.

Arikunto, Suharsimi. Proses Penelitian Suatu Pendekatan Praktik. Jakarta: PT. Rineka Cipta,2006.

Al-Sijistani, Abu Dawud Sulaiman bin al-Asy'ats al-Azdi. Sunan Abu Dawud, Jilid II Lebanon: Dar al-Kotob Al-Ilmiyah, 2011.

Buna'i. Penelitian Kualitatif. Malang: Perpustakaan STAIN Pamekasan Press. 2008.

Departemen Pendidikan Nasional, Kamus Besar Bahasa Indonesia Pusat Bahasa,Edisi keempat. Jakarta: PT Gramedia Pustaka Utama, 2008.

Emzir. Metodologi Penelitian Kualitatif Analisis Data. Jakarta: PT Raja Grafindo Persada, 2012.

Faiz el Muttaqin, Abdul Wahhab Khallaf ed. Ilmu Ushul Fikih. Jakarta: Pustaka Amani. 2003.

Hasbiyallah. Figh dan Ushul Figh. Bandung, PT Remaja Posdakarya.2017.

Herdiansyah, Haris. Wawancara, Observasi, dan Focus Groups. Jakarta: PT Raja Grafindo Persada, 2013.

Jalil, Abdul. Al-Qawaid al-Fiqhiyyah. Surabaya: Pena Salsabila. 2013. 
Pandangan Masyarakat Tentang Tradisi Dhempo' dalam Proses Pertunangan (Studi Kasus di Desa Jarin Kecamatan Pademawu Kabupaten Pamekasan)

Kasiram, Moh. Metodelogi Penelitian Kualitatif Kuantitatif. Malang: UIN Maliki Press, 2010.

Kementrian Agama RI, Al-Quran dan Terjemahan. Bandung: CV Media Fitrah Rabbani, 2009.

Kompilasi Hukum Islam, Bandung:Citra Umbara, 2016.

Koto, Alaidin. Ilmu Figh dan Ushul Figh. Jakarta: Raja Grafindo Persada. 2014.

L. Pals, Daniel. Dekontruksi Kebenaran Kritik Tujuh Teori Agama, Yogyakarta: IRCiSoD, 2001.

Media, Sakera. "Tradisi Pertunangan di Madura", Emadura, diakses dari http:/ / www.emadura.com/2015/06/tradisi-pertunangan-dimadura.html, pada tanggal 26 februari pukul 20:08.

Moleong, Lexy J., Metodologi Penelitian Kualitatif. Bandung: PT. Remaja Rosdakarya, 2011.

Moleong, Lexy J., Metodologi Penelitian Kualitatif edisi revisi. Bandung: PT Remaja Rosdakarya, 2017.

Musawwamah, Siti., Hukum Perkawinan. Pamekasan: STAIN Pamekasan press, 2010.

N. Fathurrahman, \& Amiruddin. Pengantar Ilmu Figh. Bandung: Reflika Aditama. 2016.

Nuruddin, Amiur \& Azhari Akmal Tarigan, Hukum Perdata Islam di Indonesia. Jakarta: Kencana,2004.

Pedoman Penulisan Karya Ilmiah. Pamekasan: STAIN Pamekasan Press, 2012.

Saebani, Beni Ahmad. Figh Munakahat. Bandung: CV Pustaka Setia, 2001.

Soemodidjojo, Raden. Kitab Primbon BETALJEMUR ADAMMAKNA Bahasa Indonesia. Solo: CV Buana Raya, 1997.

Somad, Abd. Hukum Islam Penormaan Prinsip Syariah dalam Hukum Indonesia. Jakarta: Kencana, 2010.

Sugiyono. Metode Penelitian Kuantitatif Kualitatif dan RED. Bandung: Alfabeta, 2010.

Suhaimi. "Praktik Khitbah di Madura Perspektif Hukum Islam dan Hukum Adat", Al-Ihkam VOL 9 No.2. Desember, 2014.

Syarifuddin, Amir. Garis-Garis Besar Fiqih. Jakarta: Kencana, 2003.

Warsita, Toty Citra. "Prosesi Peminangan Menurut Adat Bima dalam Prespektif Islam". Skripsi, UIN Syarif Hidayatullah, Jakarta, 2010. 
Fahrisal Amin

Zenrif, MF. Realitas Keluarga Muslim antara mitos dan doktrin agama. Malang: UIN-Malang Press, 2008. 